\title{
Validity of LKPD based constructivism approachment
}

\author{
Dini Fajria Trisna ${ }^{1}$, Hendra Syarifuddin ${ }^{2}$, Ratnawulan ${ }^{3}$ \\ ${ }^{123}$ Universitas Negeri Padang, Padang - Indonesia, (dfajriatrisna@gmail.com)
}

\begin{abstract}
Problem solving ability is one of the mathematical abilities that are important in the success of students. But the fact remains low problem solving ability. One approach that can develop problem solving ability is constructivism approachment. The constructivism approach is one of the learning approaches which can trigger students to build their own knowledge and help students find their own mathematical principles or procedures. LKPD is one important component in learning. LKPD used by teachers not specifically describe the learning process, as well as yet to be seen developing students' problem solving abilities. This study aims to determine the validity of LKPD based on constructivism approach. This research is a development research by using Plomp model which consists of preliminary research, development stage and assessment phase. The results of data analysis show that the developed LKPD has been valid with the validity index of 0,848 so it can be used to increase problem solving student ability.
\end{abstract}

Keywords: constructivism approachment, LKPD, validity, plomp.

\section{Introduction}

Mathematics is one of the areas of study that had a role in education and studied at every level of education from elementary, junior high school to university. Moreover, the mathematics also serves to solve the problems of everyday life. One obvious example that is often seen is in the process of buying and selling. Besides mathematics is also required in other disciplines, such as social sciences and natural sciences. Math in school have a goal to be achieved by learners. The purpose of learning mathematics by Permendikbud No. 58 of 2014 regarding curriculum SMP / MTS covers several aspects of ability, namely the understanding of the mathematical concepts, reasoning, and problem solving, communication of ideas / idea, to have an attitude appreciate the usefulness of mathematics in life, an attitude appreciate the usefulness of mathematics in life, performing motor activities that use mathematical knowledge, using simple props as well as the results of the technology to perform the activities of mathematics. Based on these objectives, it appears that the problem-solving ability is an important thing to be possessed of learners in mathematics, because of this ability have a positive impact in the lives of students to solve problems in their daily lives. It is also described by Branca (Purnomo, 2014) that the problem-solving ability is a primary goal in mathematics, and therefore should be given the ability to solve problems, trained and accustomed to students as early as possible.

Hudoyo (1988: 142) also states that teaching problem solving to students, allowing learners become more analytical in making decisions in his life. That is, when learners are trained to solve the 
problem, then learners will be able to take a decision, because such learners have become skilled on how to collect relevant information, analyze information, and realize how necessary to re-examine the results already obtained.

Based on the results of studies conducted by the Program of International Student Assessment (PISA) conducted by the Organization for Economic Cooperation and Development (OECD)or the organization for economic cooperation and development in 2012. In the PISA study results Indonesia is still not able to show even greater success well in the areas of reading, science and mathematics. Indonesia ranks only 64th out of 65 participating countries in the field of mathematics. "Problems in the PISA mathematics more measure problem-solving abilities, reasoning, arguing and communication skills" (Sri and Rumiati, 2011: 51). This shows that the mathematical skills of students in Indonesia is still alarming.

Based on the observations at SMPN 1 Padang Gelugur and SMPN 4 Lubuk Sikaping on the learning process undertaken, the learning that happened only one direction only (teacher centered). The learning process is done directly by explaining the subject matter and sample questions. LKPD provided in the school has not been able to support the learning process that aims to improve the mathematical ability of learners, especially the problem solving ability of mathematical learners. The LKPD provided generally contains brief information on instructional materials, examples of materials implementation and exercises in the form of multiple choice questions and descriptions. In other words in LKPD available learners are more emphasized just to develop the ability to count only

LKPD should be able to be utilized as a supporting tool that can facilitate students to actively participate in learning. The concept that should be known to students should not be presented instantly but is the result of the construction of the students themselves by optimizing the initial knowledge that has been owned. In order for this construction process to run easier for learners, the teaching materials used should be arranged in such a way that is more interesting, easy to understand and used by learners.

Based on these problems, it is necessary to prepare and develop LKPD that can help the success of the learning process in the classroom. LKPD developed should be able to facilitate teachers and learners in achieving the goals of learning mathematics. One alternative that can overcome these problems is to develop a device based on mathematics learning constructivism approach.

Constructivism as described by Sagala (2009: 88), is the foundation of the philosophy of the contextual approach of which knowledge is built little by little, whose results are expanded through abrupt and non-abrupt contexts. Knowledge is not a set of facts, concepts or rules that are ready to be taken and remembered.

In the early stages of learning using constructivism approach, learners are guided to build knowledge of the material to be studied by answering material related questions. Furthermore, learners are helped to express his idea clearly by discussing, writing, drawing, and others to build his knowledge and conclude about the knowledge he has gained. When learners can build their knowledge and understand the concepts that exist in the material, then the material can be attached longer to the memories of learners, so not just memorize but understand the material.

Teachers can provide convenience for this process, by allowing learners to discover or apply their own ideas, and teach learners to realize and use their own strategies for learning. LKPD based constructivism contains how learners build their knowledge. LKPD is made gradually for learners in solving the given problem. Based on the exposure, research will be conducted on the development of constructivism-based learning tools that are expected to make students more active, creative and motivated so that students can solve the problem well. Through learning by using constructivism approach, learners are expected to be really active in learning so as to express their ideas and find their own concepts and principles learned. 
In the development of this learning device produced products in the form of LKPD with product quality in terms of validity. Validity in development research includes content validity (relevancy) and construct validity (consistency). According to Nieveen (1999), validity leads to the feasibility of instructional tools, both in content and construct. A learning device is said to be valid or feasible to use if the contents and contructs are appropriate and interconnected to facilitate users both teachers and learners.

Validity LKPD developed in this study assessed based on the results of expert assessment of experts, consisting of mathematics education experts, linguists and technology experts education. Learning device be valid if the data analysis LKPD validation sheet in the category valid. The development research done to see the validity of the mathematical LKPD constructivist approach to be used in the learning process of mathematics.

\section{Methods}

The study is a research \& development (Research and development). The model used is a model development Plomp which consists of three phases, namely: a preliminary analysis phase, phase of development of prototypes and assessment phase.

1. Preliminary investigation stage (preliminary research)

At this stage, identification or analysis of the things needed for the development of the LKPD based constructivism approach. The purpose of this phase is to establish and define the requirements needed in the development of the RPP and LKPD. At this stage, there are four basic steps are: (1) Analysis of needs, do collect information on issues contained in the teaching of mathematics in schools. (2) Curriculum analysis, an analysis of the curriculum used in SMP Negeri 4 Lubuk Sikaping. This analysis is necessary to study the core competencies and basic competencies, learning objectives, the range of material, and the formulation of learning indicators. (3) Analysis of learners, aims to understand the characteristics of learners that includes: academic skills, passion for color and image, the tendency of learners in the learning and the difficulties faced by learners and learning such as what is desired by learners. (4) Concept analysis, carried out activities to identify, specify and compile systematically main material to be learned by the learners. Analysis of the concept aims to identify concepts, facts, principles and procedures that must be mastered by the learner.

The results of the preliminary analysis phase of analysis used as the basis for LKPD development is based on constructivism approach.

2. Development or manufacture prototype (development or prototyping phase),

In the prototyping phase, prototyping is done formative evaluation. At this stage, things to do, namely designing LKPD based constructivist approach based on the information obtained in the stages of preliminary research. At this stage, the main measures undertaken by the researchers are: (1) Self-evaluation, a correction back by researchers to LKPD as designed. Once revised, the result is called a prototype 1. (2) Expert review, the correction of the LKPD conducted by some experts experts predetermined. Once revised and declared valid, the result is called a prototype 2. (3) One to one evaluation, an evaluation of the LKPD performed by an individual with the ability level is different. Once revised, the result is called a prototype 3. (4) Small group evaluation, an evaluation of the LKPD conducted by six (6) students with different ability levels vary. After the revision, the result is called a prototype 4 .

3. Assessment phase. At the stage of assessment (assessment phase)

The phase of the assessment phase is to test the effectiveness of the resulting product field test (field test) in class VII SMPN 4 Lubuk Sikaping to see the practicality and effectiveness. The research data was collected through validation sheet, teacher's and student's response 
questionnaire, observation sheet of implementation, and the result of students' reasoning ability test. Based on the methods that have been described previously, the development carried out in this study only focuses on the process of validation stages of LKPD developed.

\section{Results and Discussion}

\section{Preliminary Research Results}

Activity this preliminary analysis into the early stages of research. The activities undertaken preliminary analysis is activity needs analysis, curriculum analysis, concept analysis, and analysis of the students. Based on the results of a needs analysis obtained information that the learning process is carried out is still dominated by teachers, learning steps are executed is a step-by-step routine, such as: the teacher gives the concept with examples of problems, and then the students do exercises similar to the questions that have been awarded the teacher. Teachers do not get used to learning presents problems to train the students problem solving abilities. So that students have difficulty when faced with the problem solving.

At this stage, identification or analysis was needed for LKPD development based on constructivism approach. Based on observations and interviews conducted to teachers of grade VII SMPN 4 Lubuk Sikaping obtained some information, namely: LKPD was enough to help learners to practice doing mathematics problems both at school and at home, but the LKPD had not been able to optimize the ability of learners to train their mathematical problem solving skills, because the material in LKPD is presented in a straightforward, concise way and not accompanied by the process of obtaining it, thus not facilitating students to build their knowledge.

Therefore, LKPD was developed based on a constructivism approach that contains students' activities in finding concepts through questions that guide and direct students on what is being studied. Students will follow the instructions based on the answers of the questions that students make, so that students can find the concept of what is being learned in its own way and discuss with friends.

2. Results Prototyping Phase (design prototype)

The LKPD designed was LKPD based on the approach of construtivism. The design of LKPD starts from the didactic or presentation aspect. Things to consider in the presentation that was, provide problems in everyday life related to the material being studied. Furthermore, the content aspect, the things that were considered in the content of LKPD were presented in accordance with the indicators of achievement of competence. In addition, viewed from the aspects of the language, the matter of note that was, the writing and language used adapted to the Indonesian spelling abbreviated EBI. The final stage to note that aspects of the display, the note is the overall appearance of LKPD designed to suit students' character class VII.

After the learning device is designed, then do self-evaluation to see typing errors, the errors of punctuation, the errors of the size of the paper, the relevance of the drawing and the illustrations provided, the availability of blank spots to answer the questions is then corrected and validated to the competent experts in their respective fields.

Furthermore, the validation activities are done in the form of filling validation sheet and discussion. Validation stages in LKPD done with two stages namely (1) validation of the instrument; and (2) LKPD validation. During the validation process there are several revisions suggested by the validator. After the repairs are made, the validators provide an assessment. These stages can be described as follows.

Instrument Validation 
Instrument Validation was an assessment performed by several validators of the instrument. Validation of instruments to be assessed by validators to validate learning tools in the form of LKPD is LKPD instrument validation sheet. Assessment of validation of this instrument is done by three validators (expert experts) ie two lecturers of mathematics education and one lecturer of Indonesian language. Based on the results of the validator assessment it is stated that the validity of LKPD instruments based on constructivism approach is categorized as "Valid" with average of validity index 0.792 .

\section{LKPD Validation}

Validation of learning tools in the form of LKPD based on constructivism approach is assessed from several aspects, namely: (1) Didactic Aspects and Content; (2) Language Aspects; and (3) Aspect of graphics or appearance. The assessment was conducted by five experts consisting of three lecturers of Mathematics Education to validate LKPD based on didactic and content aspects, one lecturer of language based on language aspect and one lecturer of education technology based on aspect of graphics or appearance. LKPD validation results can be described as follows.

1. Aspects of DiDaktik and Content

Based on the result of validator assessment it is stated that LKPD based on constructivism approach seen from didaktik aspect and the contents are categorized "Valid" with the average of validity index 0,820 .

\section{Language Aspects}

Based on the result of validator assessment it is stated that LKPD based on constructivism approach seen from the language aspect is categorized "Valid" with the average of validity index 0,867 .

3. Aspects of kegrafikaan and Display

Based on the result of the validator assessment it is stated that LKPD based on constructivism approach seen from the aspect of kegrafikaan or display categorized "Valid" with the average of validity index 0,857 .

Overall the validity of LKPD based on constructivism approach have fulfilled valid criterion with average of index of validity and 0,848 .

\section{Conclusions}

The learning tools based on constructivism approach developed are valid both in content and construct. The result of validation from mathematic expert obtained by LKPD based on constructivism approach has been valid to the aspect of content and didaktik. The validation result from the language expert obtained by LKPD based on constructivism approach is valid and the language used is in accordance with EBI. Likewise the results of validation from educational technology experts obtained LKPD-based constructivism approach has been valid to the aspect of kegrafikaan. So it can be used in the learning process of mathematics.

\section{Acknowledgments}

With the completion of this research, the researcher would like to thank Mr. Drs. Hendra Syarifuddin, M. Si, Ph.D and Ms. Ratnawulan, M.Si and lecturers of Post-Graduate of Universitas Negeri Padang who have provided guidance with sincere heart and patience in completing this journal. This journal is prepared based on the thesis Dini Fajria Trisna entitled Development of 
Learning-Based Devices Constructivism Approach To Improve Mathematical Problem Solving Ability Class VII Junior High School Students.

\section{References}

Barmby, P. et al. (2007). How Can We Assess Mathematical Understanding?.In Woo, J. H., Lew, H. C., Park, K. S. \& Seo, D. Y. (Eds.). Proceedings of the 31st Conference of the International Group for the Psychology of Mathematics Education. Vol. 2, pp. 41-48. Seoul: PME.

Bodner, G.M. (1986). Constructivism: A Theory of Knowledge. Journal of Chemical Education. 63, 873878.

Kamus Besar Bahasa Indonesia Edisi ke 4 Pusat Bahasa. (2008). Departemen Pendidikan Nasional. Jakarta: PT. Gramedia Pustaka Utama.

Kemdikbud. (2016). Buku Guru Matematika SMP/MTs Kelas VII. Jakarta: Kemeterian Pendidikan dan Kebudayaan.

National Council of Teachers of Mathematics (NCTM). (2000). Principles and Standards for school Mathematics, Restron, VA: NCTM.

Peraturan Menteri Pendidikan Nasional Nomor 58 Tahun 2014 tentang Kurikulum SMP. (2013). Jakarta: Kemendikbud.

Plomp, Tjeerd. (2013). An Introduction to Educational Design Research :SLO - Netherlands Institute for Curriculum Development.

Sagala, Syaiful. 2011. Kemampuan Profesional Guru dan Tenaga Kependidikan. Bandung: Alfabeta.

Sri Wardhani dan Rumiati. (2011). Modul Matematika SMP Program Bermutu: Instrumen Penilaian Hasil Belajar Matematika SMP Belajar dari dari PISA dan TIMSS. Yogyakarta: PPPPTK Matematika. (diakses 20 Agustus 2016 dari p4tkmatematika.org).

Suherman, Erman, dkk. (2003). Strategi Pembelajaran Matematika Kontemporer. Bandung: Fakultas Pendidikan MIPA Universitas Pendidikan Indonesia. 